\title{
SUPERVISI INDIVIDUAL DALAM PENINGKATAN KINERJA GURU KELAS DALAM MENYUSUN RPP DI MTSN 2 BUTON TENGAH SULAWESI TENGGARA
}

\author{
KARIM \\ MTsN 2 Buton Tengah, Sulawesi Tenggara \\ E-mail : karimlapitara@gmail.com
}

\begin{abstract}
ABSTRAK
Tujuan penelitian ini adalah untuk meningkatkan kinerja guru kelas di MTsN 2 Buton Tengah Sulawesi Tenggara. Penelitian ini dilakukan karena peneliti merasa kinerja guru masih cenderung tidak stabil. Hal ini dikarenakan beberapa faktor antara lain adalah rendahnya motivasi guru, dan kompetensi guru yang belum sepenuhnya dikuasai oleh semua guru. Permasalahan tersebut diharapkan dapat diatasi melalui pendampingan terhadap guru melalui supervisi individual dengan pendekatan kolaboratif dalam proses pelaksanaan pembelajaran. Prosedur penelitian ini adalah dengan penelitian tindakan (action research) yang dilaksanakan dengan dua siklus. Tiap siklus terdiri dari empat tahap yaitu Pererncanaan; Pelaksanaan; Observasi; dan Refleksi. Berdasarkan hasil penelitian tindakan sekolah dapat disimpulkan: 1) peningkatan presentase kinerja guru kelas MtsN 2 Buton Tengah dari refleksi awal 52,5\%, setelah dilakukan tindakan siklus I naik menjadi $67,7 \%$, dan pada tindakan siklus II menjadi $77,8 \%$; 2) Supervisi individual dengan pendekatan kolaboratif memberikan pengaruh terhadap peningkatan kinerja guru kelas di MTsN 2 Buton Tengah.
\end{abstract}

Kata Kunci: supervisi individual; kinerja guru

PENDAHULUAN

Tugas pokok seorang guru sebagai tenaga pendidik meliputi ; merencanakan pembelajaran, melaksanakan pembelajaran, mengevaluasi hasill pembelajaran, dan menganalisis hasil pembelajaran sebagai bahan perbaikan (remedial) dan pengayaan. Selama ini menurut pengamatan peneliti kemampuan guru dalam menyusun rencana pelaksanaan pembelajaran (RPP) masih perlu sangat dilatih dan diasah terus menerus. Hal ini kemungkinan karena kemampuan dan wawasan guru tentang penyusunan RPP masih kurang. Tidak heran jika pengadaan RPP masih cenderung hanya sekedar copy paste dari contoh RPP yang sudah ada.

Dari kondisi tersebut maka perlu adanya pendampingan dalam bentuk supervisi individual kolaboratif agar guru termotivasi dan memahami model pembelajaran pendekatan tematik dari perencanaannya dan pelaksanaan (materi, media belajar, metode, sumber belajar, dan evaluasi) sehingga pembelajaran tematik menjadi suatu yang utuh tidak dilaksanakan secara parsial, secara berkenjutan dalam satu tema yang saling berkorelasi dengan mata pelajaran yang relevan.

Supervisi pendidikan terhadap guru (pendampingan), arti dan pentingnya supervisi. Pesatnya poerkembangan ilmu pengetahuan dan teknologi disatu puhak, kemajuan perkembangan masyarakat serta aspirasi nasional dalam krmajuan bangsa dan umat dilain pihak, membawa konsekuensi serta tanggung jawab yang sangat berat dan kompleks bagi pelaksana sektor pendidikan pada umumnya dan guru khususnya. Hal ini menuntut guru untuk bisa lebih profesional dalam menjalankan tugasnya. Profesional sering diartikan sebagai suatu ketrampillan teknis yang dimiliki seseorang. Sahertin dalam Deni Koswara (2008), mengatakan bahwa profesional mempunyai makna ahli (expirt), tangung jawan (responsibiliti), baik tanggung jawab intelektual maupun tanggung jawab moral dan memiliki rasa kesejawatan. Untuk mewujudkan hal tersebut, peran Kepala Sekolah sangat penting, karena guru butuh oendampingan untuk dapat melaksanakan tugasnya secara maksimal. Salah satu upaya yang dapat dilaksanakan oleh kepala sekolah untik mendampingi guru agar dalam melaksanakan tugasnya dapat lebih baik adalah dengan supervisi.menurut 
Boardman dalam Akhmad Rokhani dan Abu Akhmad (1990), supervisi adalah suatu kegiatan menstimulir, mengkoordinasi, dan membimbing secara kontiniu pertumbuhan guru- guru sekolah, baik secara individual maupun secara kolektif, agar lebih mengerti, dan lebih efektif dalam mewujudkan seluruh fungsi pengajaran, sehingga dengan demikian mereka mampu dan lebih berpartisipasi dalam masyarakat modern. Berdasarkan pendapat tersebut dapat disimpulkan bahwa supervisi mmpunyai beberapa fungsi yaitu (a) fungsi pelayanan, yaitu kegiatan pelayanan untuk peningkatan profesionalnya, (b) fungsi penelitian, yaitu untuk memperoleh data yang obyektif dan relefan, misalnya untuk menemukan hambatan belajar, (c) fungsi kepemimpinan, yaitu usaha mempengaruhi orang lain agar yang disupervisi dapat memecahkan masaah sendiri sesuai dengan tanggunjawab profesionallnya, (d) fungsi manajemen, yaitu supervisi dilakukan sebagai kontrol atau pengarah, sebagai aspek manajemen, (e) fungsi evaluasi, yaitu supervisi dilakukan untuk mengevaluasi hasil atau kemajuan yang diperoleh, (f) fungsi bimbingan, (g) fungsi pendidikan dalam jabatan (inservice educations) khususnya bagi para guru muda. Kinerja guru, menurut Gibson, J.L.dkk (1996) adalah perilaku yang ditunjukkan oleh individu dalam mengerjakan suatu tugas yang dibebankan.

Kinerja adalah ungkapan kemajuan yang didasari oleh pengetahuan, sikap dan ketrampilan dalam menghasilkan sesuatu. Namun menurut Yaslis Ilyas (2001) mengatakan kinerja adalah penampilan hasil karya personil, baik kuantitas maupun kualitas dalam suatu organisasi. Dengan demikian kinerja adalah perilaku individu sebagai ungkapan kemajuan dalam menghasilkan sesuatu yang diperoleh dengan mendayagunakan pengetahuan, sikap, dan ketrampillan yang dimiliki.

Konsep pembelajaran tematik mengintegrasikan antar konsep, antar pokok bahasan dalam satu mata pelajaran bahkan atar pokok bahasan/tema pada mata pelajaran lain, sehingga model pembelajaran tematik sering juga disebut model pembelajaran terpadu. Hakikat pembelajaran terpadu merupakan suatu sistem pembelajaran yang memungkinkan siswa (secara individu maupun kelompok) aktif mencari menggali dan menemukan konsep serta prinsip keilmuan secara holistik, bermakna, dan autentik (Najib, 2010).

Perencanaan pembelajaran tematik; Model pembelajaran tematik merupakan model pembelajaran yang pengembangannya dimulai dengan menentukan topik tertentu sebagi tema atau topik sentral, setelah tema ditetapkan maka selanjutnya tema itu dijadikan dasar untuk menentukan dasar sub-sub tema dari bidang study lain yang terkait (Fogarty, 1991). Penetuan tema dapat dilakukan oleh guru melalui tema konseptual yang cukup umum tetapi produktif. Dapat pula ditetapkan dengan negoisasi antara guru dengan siswa, atau dengan cara diskusi sesama siswa. Alwasilah,dkk (1998) menyebutkan bahwa tema dapat diambil dari konsep atau pokok bahasan yang ada disekitar lingkungan siswa, karena itu tema dapat dikembangkan berdasarkan minat dan kebutuhan siswa yang bergerak dari lungkungan terdekat siswa dan selanjutnya beranjat ke lingkungan terjauh siswa.

\section{METODE PENELITIAN}

Penelitian ini dilaksanakan dengan menggunakan desain penelitian tindakan (aktion reserch) yang dirancang melalui dua siklus, melalui prosedur: (1) perencanaan (planing), (2) pelaksanaan tindakan (aktions), (3) pengamatan (observation), (4) refleksi (reflektions) dalam tiap-tiap siklus. Teknik analisis data, data yang terkumpul dalam penelitian ini dianalisis secara kualitatif dan kuantitatif. Data kualitatif dianalisis dengan menggunakan analisis model interaktif, yaitu analisis yang dilakukan melaui 3 kegiatan, menurut Miles dan Huberman (1992), komponen analisisnya meliputi: reduksi data, penyajian data (display), penarikan kesimpulan. Data kuantitatif dianalisis dengan menggunakan analisis deskriptif. 


\section{HASIL DAN PEMBAHASAN}

Hasil refleksi awal terhadap kinerja guru kelas di MTsN 2 Buton Tengah dalam menyusun rencana pelaksanaan pembelajaran, sebelum dillakukan tindakan pada siklus I, berdasarkan dokumen RPP yang sudah ada, didapatkan tingkat kinerja guru seperti disajikan pada grafik sebagai berikut:

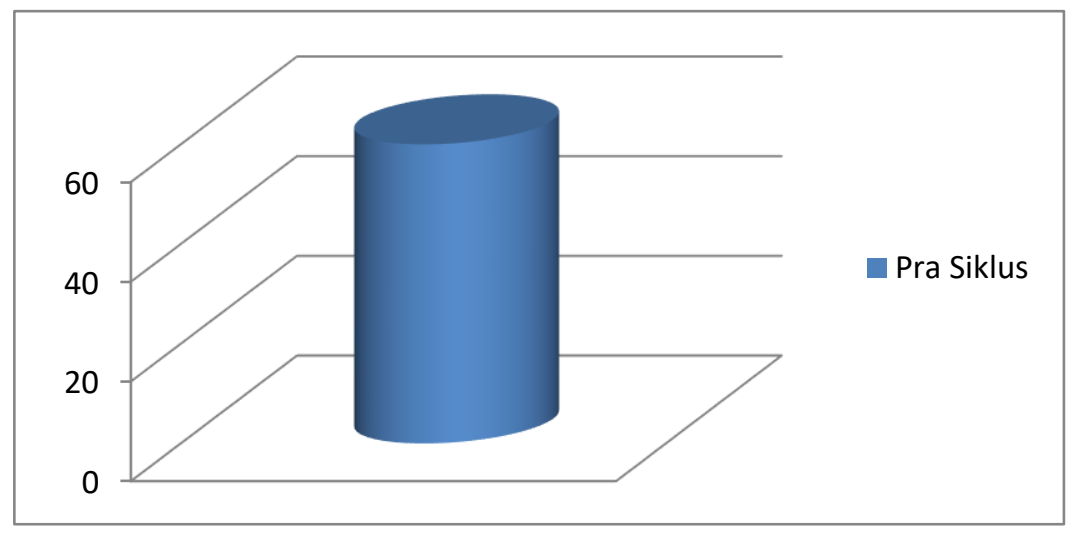

Grafik 1. Pra Siklus

Aspek menentukan perbaikan pembelajaran dan merumuskan tujuan/ indikator perbaikan pembelajaran memiliki skor $60 \%$, pada aspek ini guru dalam menyusun tujuan dan indikator sesuai dengan kurikulum dan permasalahan yang diperbaiki disertai penjelasan tetapi masih singkat. Aspek mengembangkan dan mengorganisasikan materi, media (alat bantu pembelajaran), dan sumber belajar 55\%, dipengaruhi bahwa guru merencanakan lebih dari satu media. Sedangkan aspek perencanaan skanario pembelajaran mencapai 50\% diaspek ini sebagian guru sudah mencantumkan langkah pembukaan, inti, dan penutup secara rinci dan sesuai dengan tujuan/indikator atau materi perbaikan pembelajaran. Merancang pengelolaan kelas perbaikan pembelajaran mencapai skor $45 \%$, pada aspek ini masih rendah sebab model pembelajarannya masih konvensional. Aspek merencanakan prosedur, jenis dan menyiapkan alat penilaian perbaikan pembelajaran memperoleh skor $50 \%$, hal ini ditandai guru dalam menyusun prosedur dan atau jenis penilaiannya belum sesuai dengan indikator atau tujuan. Aspek yang paling akhir adalah tampilan dokumen rencana perbaikan pemblajaran memperoleh skor 55\% penampilan fisik rencana perbaikan pembelajaran sudah baik, namun sebagian guru belum menggunakan tata tulis yang baik dan benar.

\section{Siklus I}

Hasil refleksi awal dijadikan sebagai dasar untuk melakukan tindakan siklus I yaitu supervisi kolaboratif dengan pendekatan individual terhadap guru MTsN Buton Tengah Sulawesi Tenggara. Permasalahan- permasalahan yang dihadapi oleh guru dalam menyusun RPP perlu diperbaiki.

Dari hasil penelitian terlihat bahwa kinerja guru kelas I setelah dilakukan supervisi individual dengan pendekatan kolaboratif didapatkan presentasi skor kinerja mengalami peningkatan dari 52,5\% menjadi 67,7\%. Peningkatan kinerja tersebut berdasarkan kategori presentase termasuk pada kategori yang tinggi, perhatikan grafik berikut: 


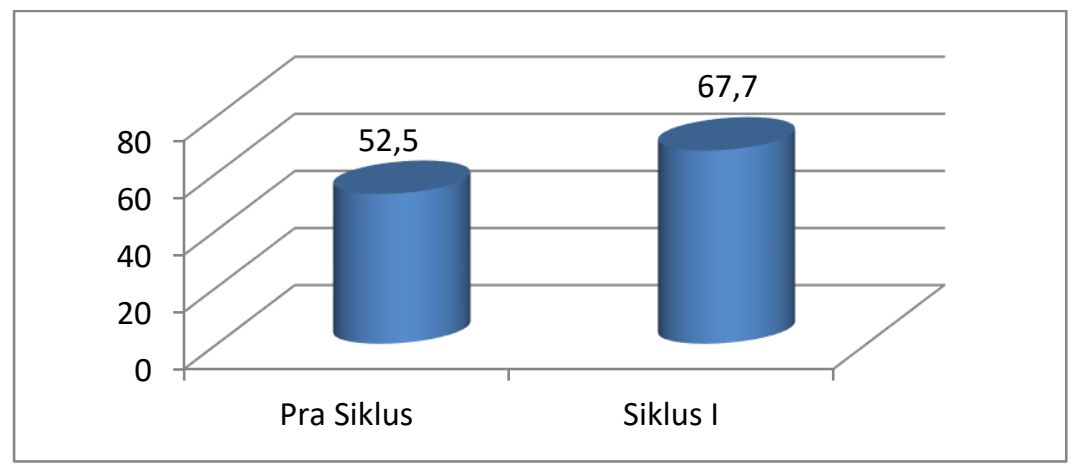

Grafik 2 : Kategori Kinerja Guru Kelas I Siklus I

Jika dibandingkan dengan kategori kinerja refleksi awal setiap aspek mengalami perubahan presentase. Aspek menentukan perbaikan pembelajaran dan merumuskan tujuan/indikaor perbaikan pembelajaran refleksi awal 60\% naik menjadi $75 \%$. Aspek mengembangkan dan mengorganisasikan materi, media (alat bantu pembelajaran), dan sumber belajar refleksi awal 55\% naik menjadi 76,7\%. Aspek merencanakan skenario pembelajaran refleksi awal 50\% naik menjadi 62\%. Aspek merancang pengelolaan kelas perbaikan pembeajaran refleksi awal $45 \%$ naik menjadi $52 \%$. Aspek perencanaan prosedur, jenis, dan menyiapkan alat penilaian perbaikan pembelajaran refleksi awal $50 \%$ naik menjadi $65 \%$. Aspek tampilan dokumen rencana perbaikan pembelajaran refleksi awal 55\% naik menjadi $75,3 \%$.

Kenaikan presentasi aspek ke satu adalah 50\%, hal ini ditandai dengan tercapainya indikator menggunakan bahan perbaikan pembelajaran yang sesuai dengan kurikulum dan masalah yang diperbaiki, sesuai dengan kurikulum dan penjabaran secara rinci, sedangkan indikator merumuskan tujuan khusus/indikator perbaikan pembelajaran menunjukkan kejelasan, merupakan jabaran dari kompetensi.

Presentase pada aspek ke dua naik 21,7\% kenaikannya sangat tinggi, pada masingmasing indikator baik. Mulai dari mengembangkan dan mengorganisasikan materi pembelajaran, tidak ada perencanaan penggunaan allat bantu perbaikan pembelajaran (media). Memilih sumber belajar disesuaikan dengan materi yang akan diajarkan, dan kesesuaian sumber belajar dengan tujuan dan indikator.

Aspek ketiga merencanakan skenario perbaikan pembelajaran naik yaitu $12 \%$ diawali dari indikator perbaikan pembelajaran yang dirancang sesuai dengan tujuan, sesuai dengan bahan yang akan diajarkan, sesuai dengan perkembangan anak, hanya alokasi waktunya belum semua guru menentukan dengan tepat dan cermat. Indikator langkah-langkah pembelajaran dari pembukaan, inti, dan penutup sudah cukup sesuai. Cara memotivasi siswa mencapai dua deskriptor, dan terdapat peretanyaan pemahaman.

Aspek keempat hanya mengalami kenaikan $7 \%$ penataan ruang dan fasilitas belajar serta pengorganisasian siswa masih sangat perlu ditingkatkan. Sedangkan aspek kelima naik $15 \%$ yaitu prosedur, jenis, dan menyiapkan alat penilaian tidak tercantum prosedur atau jenis penilaian yang sesuai dengan tujuan atau indikator. Indikator membuat alat-alat penilaian dan kunci jawaban, setiap soal sudah mengukur TPK atau indikator.

Aspek ke enam kenaikannya mencapai 20\%, kebersihan dan kerapihan serta penggunaan bahasanya mengalami peningkatan yang sangat signifikan.

\section{Siklus II}

Hasill refleksi pada siklus I dijadikan sebagai dasar untuk melakukan ulang supervisi kolaboratif dengan pendekatan individual terhadap guru di MTsN Buton Tengah, sebagai kelanjutan supervisi tahap pertama yaitu membantu guru mengidentifikasi 
kekurangan-kekurangan mulai dari perencanaan dakam menyusun RPP yang mereka hadapi, selanjutnya diberikan arahan-arahan yang lebih operasional dan mudah dilaksanakan oleh guru.

Dari data penelitian bahwa kinerja guru kelas I dalam menyusun RPP setelah dilakukan supervisi individual dengan pendekatan kolaboratif didapatkan presentase skor kinerja mengalami peningkatan dari $67,7 \%$ menjadi $77,8 \%$ kategori kinerja guru tersebut termasuk pada kategori tinggi yang dapat dideskripsukan dengan grafik kinerja guru hasil refleksi siklus II.

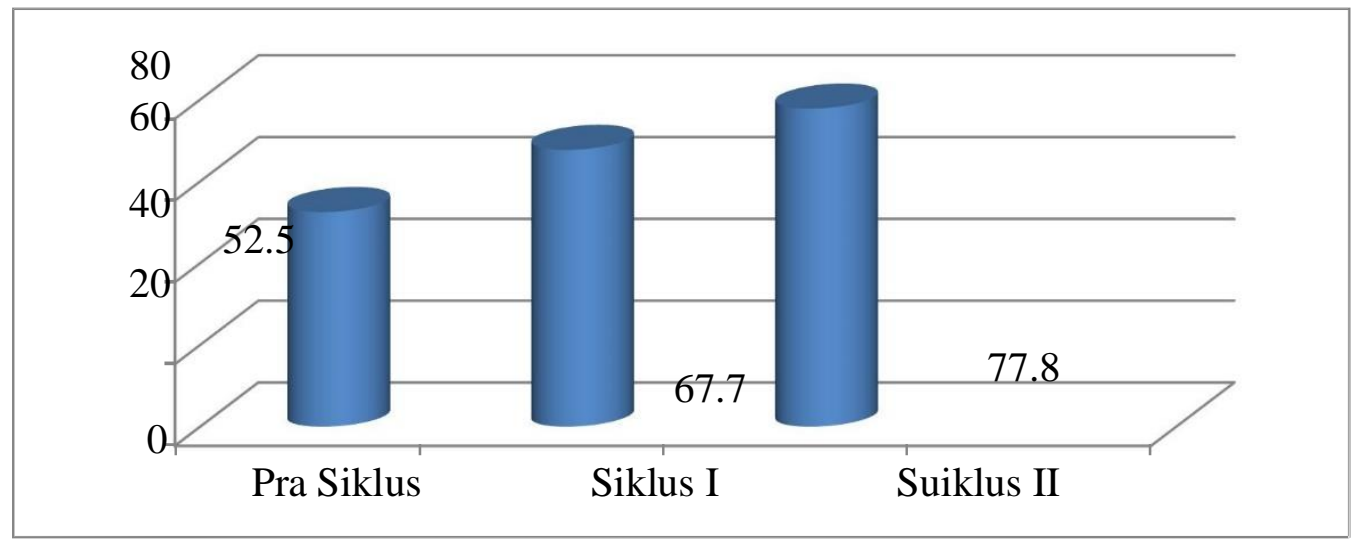

\section{Grafik 3 : Kategori Kinerja Guru Kelas I Siklus II}

Presentase semua aspek mengalami peningkatan yang sangat signifikan dengan hasil sebagai berikut:

Aspek menentukan perbaikan pembelajaran dan merumuskan tujuan perbaikan permbelajaran siklus I 75\% naik menjadi 82,5\%. Aspek mengembangkan dan mengorganisasikan materi, media, dan sumber belajar Siklus $\mathrm{I}=76,7 \%$ naik menjadi 85\%. Aspek merencanakan skenario pembelajaran di Siklus I 62\% mengalami kenaikan menjadi 69\%. Aspek merancang pengelolaan kelas perbaikan pembelajaran Siklus I 52\% naik cukup tinggi menjadi 67,5\%. Aspek merencanakan prosedur, jenis, dan menyiapkan alat penilaian perbaikan siklus I $65 \%$ naik menjadi $77 \%$. Aspek tampilan dokumen rencana perbaikan pembelajaran Siklus I 75\% naik menjadi $85 \%$.

Kenaikan persentase aspek ke satu adalah 7,5\%, hal ini ditandai dengan tercapainya satu indikator yang mendekati sempurna indikator menggunakan bahan perbaikan pembelajaran yang sesuai dengan kurikulum dan masalah yang diperbaiki, sesuai dengan kurikulum dan penjabaran secara rinci.

Persentase pada aspek ke dua hanya $8,3 \%$ persen kenaikannya. Mulai dari mengembangkan dan mengorganisasikan materi pembelajaraan, tidak ada perencanaan penggunaan alat bantu perbaikan pembelajaran (media). Aspek ketiga merencanakan skenario perbaikan pembelajaran mengalami kenaikan $7 \%$ diawali dari indikator perbaikan pembelajaran yang dirancang sesuai dengan tujuan, sesuai dengan bahan yang akan diajarkan, sesuai dengan pwerkembangan anak, sesuai dengan waktu yang tersedia, sarana dan prasarana tersedia. Aspek keempat mengalami kenaikan sangat tinggi yaitu 15,5\% penataan ruang dan fasasilitas belajar mencapai tiga deskriptor, pengorganisasian siswa mencapai tiga deskriptor. Sedangkan aspek ke lima naik $12 \%$ yaitu prosedur, jenis, dan menyiapkan alat penilaian sudah tercantum prosedur atau jenis penilaian yang sesuai dengan tujuan atau indikator. Aspek ke enam kenaikannya mencapai $10 \%$ kenaikan yang paling tinggi indikatornya mencapai empat deskriptor. Pada kebersihan dan kerapihan ,penggunaan tata tulis mencapai lima deskriptor. 
Tabel 1 : Presentase kinerja guru, awal sampai siklus I

\begin{tabular}{|c|c|c|c|c|}
\hline No & Aspek Kinerja Guru & Awal & Siklus I & $\begin{array}{c}\text { Siklus } \\
\text { II }\end{array}$ \\
\hline 1 & $\begin{array}{c}\text { Menentukan dan perbaikan } \\
\text { pembelajaran dan merumuskan } \\
\text { tujuan perbaikan }\end{array}$ & 60,0 & 75,0 & 82,5 \\
\hline 2 & $\begin{array}{c}\text { Mengembangkan dan } \\
\text { mengorganisasikan }\end{array}$ & 55,0 & 76,7 & 85,0 \\
\hline 3 & $\begin{array}{c}\text { materi, media, dan sumber } \\
\text { belajar Merencanakan skenario } \\
\text { pembelajaran }\end{array}$ & 50,0 & 62,0 & 69,0 \\
\hline 4 & $\begin{array}{c}\text { Merencanakan pengelolaan } \\
\text { kelas perbaikan pembelajaran }\end{array}$ & 45,0 & 52,0 & 67,5 \\
\hline 5 & $\begin{array}{c}\text { Merencanakan prosedur, } \\
\text { jenis, dan }\end{array}$ & 50,0 & 65,0 & 77,0 \\
\hline 6 & $\begin{array}{c}\text { menyiapkan alat } \\
\text { penilaian perbaikan }\end{array}$ & 55,0 & 75,0 & 85,0 \\
\hline & Rata-rata & 52,5 & 67,7 & 77,8 \\
\hline
\end{tabular}

Selanjutnya hasi refleksi akhir dapat dilihat peningkatan yang lebih jelas kinerja guru dari mulai tes awal, siklus I, siklus II dapat dilihat pada tabel diatas. Dari

tabel tersebut diatas nampak terjadi peningkatan yang cukup signifikan. Dari 52,5\% setelah diadakan siklus I menjadi $67,7 \%$ dan setelah diadakan tindakan siklus II menjadi $77,8 \%$, untuk lebih jelasnya dapat dilihat pada grafik di bawah ini:

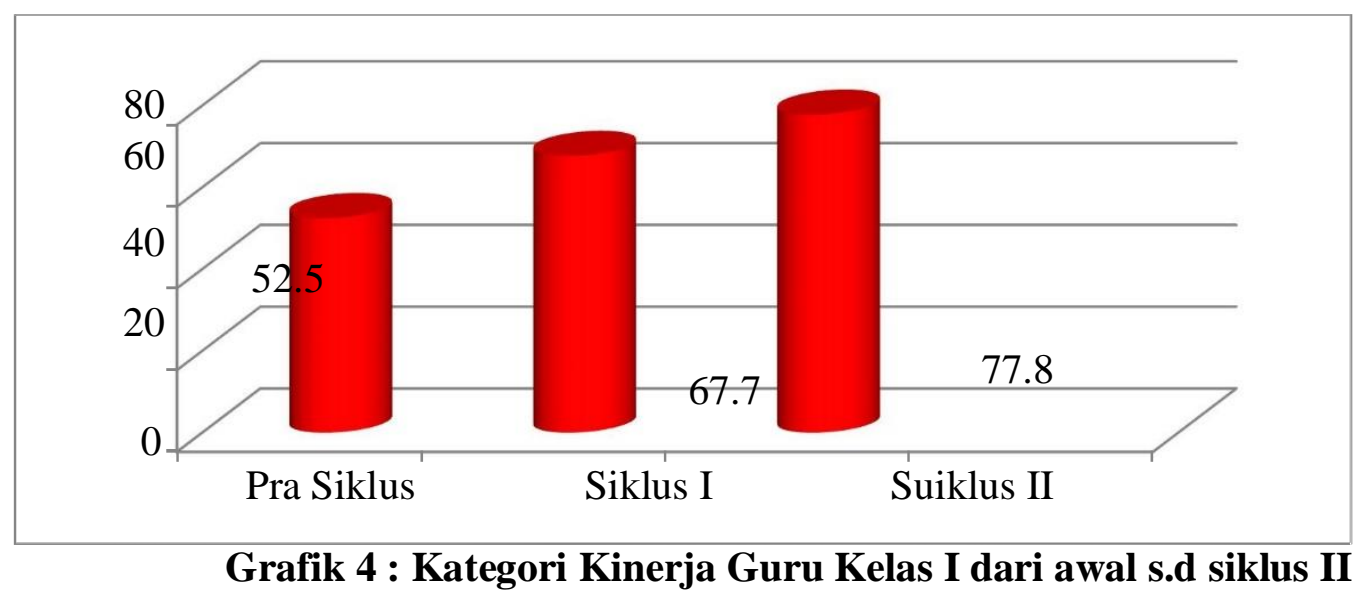

Hasil penelitian supervisi individual dengan pendekatan kolaboratif terhadap guru MTsN 2 Buton Tengah, Sulawesi Tenggara, terbukti memberikan kinerja guru yang selanjutnya berdampak peningkatan kinerja pada tugas pokok dan fungsinya salah satu yaitu pada bidang perencanaan secara kolektif menuju pada tingkat profesionalisme dan sasarannya adalah peningkatan mutu pendidikan.

\section{KESIMPULAN}

Dari hasil penelitian yang telah dilaksanakan dapat diambil simpullan sebagai berikut : 1) Supervisi individual dengan pendekatan kolaboratif memberikan pengaruh yang signifikan terhadap peningkatan kinerja guru kelas I dalam menyusun rencana pelaksanaan pembelajaran di MTsN 2 Buton Tengah; 2) Peningkatan kinerja guru berdampak pada perubahan sikap guru dalam melaksanakan tugas pokok dan fungsi guru, bahwa perencanaan pembelajaran harus dibuat oleh guru dengan cara yang baik dan benar. 


\section{DAFTAR PUSTAKA}

Agus. (2013). Peningkatan Kinerja Guru Kelas I Dalam Menyusun RPP Tematik Melalui Supervisi Individual Dengan Pendekatan Kolaboratif. Brebes (tidak dipublikasikan)

Arikunto Suharsimi. (1993). Prosedur Penelitian. Jakarta. Rineka Cipta

Departemen Pendidikan dan Kebudayaan. (1996). Pedoman Penyusunan Karya Tulis Ilmiah di Bidang Pendidikan dan Angka Kredit Pengembangan Profesi Guru. Jakarta.

Muntoso, Edi. (2013). Peningkatan Kinerja Guru Dalam Penyusunan Rencana Pelaksanaan Pembelajaran Mel- alui Supervisi Edukatif Kolaboratif Berkelanjutan.Brebes. (tidak dipublikasikan)

Najib, Muhamad.(2010).Administrasi dan Supervisi Pendidikan.Bandung Remaja Karya. Suharsimi Arikunto, (2006), Penelitian Tindakan Kelas,Jakarta,bumi Aksara.

Suhertian, Piet. (2000). Konsep Dasar dan Teknik Supervisi Pendidikan dalam Rangka Pengembangan Sumber Daya Manusia.Jakarta; Rineka Cipta.

Sulhan Najib. (2010). Pengembangan Karakter pqda Anak Manajemen Pembelajaran Guru Menuju Sekolah Efektif. Surabaya: Surabaya Intelektual Club. 